\title{
Antibacterial Activity and Major Constituents of Polyalthia cinnamomea Basic Fraction
}

(Aktiviti Antibakteria dan Juzuk Utama Fraksi Bes Polyalthia cinnamomea)

\author{
PUTERI I.A.M. MAHMUd, WAN A. YAACOB, NAZLINA IBRAHIM \& MUNTAZ ABU BAKAR*
}

\begin{abstract}
Polyalthia cinnamomea Hook.f. \& Thomson (Annonaceae) or locally known as 'Larak Batu Bukit', 'Pisang-pisang', 'Sugao' and 'Sigumpet Hutan' is a small woody plant found throughout Malaysia and Singapore. In this study, the basic chemical components from the leaves of the plant were fractionated and the antibacterial activity as well as the major constituents of the basic fraction was determined. To the best of our knowledge, this is the first study being carried out on the bioactivity and phytochemistry of $\mathrm{P}$. cinnamomea. The basic fraction remarkably inhibited the growth of ten bacteria tested except one. The biggest inhibitory diameter and the lowest minimum inhibitory concentration were 19.0 $\pm 4.6 \mathrm{~mm}$ and $0.125 \mathrm{mg} / \mathrm{mL}$ against respective Bacillus subtilis and Bacillus thuringiensis. Gas chromatography-mass spectrometry (GCMS) analysis of the basic fraction identified four major cyclosiloxanes of octamethylcyclotetrasiloxane (18.1\%), decamethylcyclopentasiloxane (16.4\%), dodecamethylcyclohexasiloxane $(14.1 \%)$ and tetradecamethylcycloheptasiloxane (6.0\%). The knowledge of the antibacterial potential of P. cinnamomea basic fraction and the major constituents present in the fraction can be utilized in the fields of natural products, pharmaceutical, cosmetic and personel care industries.
\end{abstract}

Keywords: Antibacterial activity; basic fraction; cyclosiloxane; Polyalthia cinnamomea

\section{ABSTRAK}

Polyalthia cinnamomea Hook.f. \& Thomson (Annonaceae) atau dikenali tempatan sebagai Larak Batu Bukit, Pisangpisang, Sugao dan Sigumpet Hutan merupakan tumbuhan berkayu kecil yang tumbuh di seluruh Malaysia dan Singapura. Dalam kajian ini, komponen kimia asas daripada daun tumbuhan tersebut telah difraksikan dan aktiviti antibakteria berserta juzuk utama fraksi bes tersebut telah ditentukan. Setahu kami, ini adalah kajian pertama yang dijalankan terhadap bioaktiviti dan fitokimia P. cinnamomea. Fraksi bes tersebut telah merencat secara luar biasa pertumbuhan sepuluh bakteria yang diuji kecuali satu. Diameter perencatan terbesar dan kepekatan perencatan minimum terendah adalah 19.0 $\pm 4.6 \mathrm{~mm}$ dan $0.125 \mathrm{mg} / \mathrm{mL}$ masing-masing terhadap Bacillus subtilis dan Bacillus thuringiensis. Analisis kromatografi gas-spektroskopi jisim (KGSJ) fraksi bes tersebut telah mengenal pasti empat siklosiloksana utama, iaitu oktametilsiklotetrasiloksana (18.1\%), dekametilsiklopentasiloksana (16.4\%), dodekametilsikloheksasiloksana (14.1\%) dan tetradekametilsikloheptasiloksana (6.0\%). Pengetahuan potensi antibakteria fraksi bes P. cinanamomea dan komponen utama yang hadir dalam fraksi tersebut boleh dimanfaatkan dalam bidang hasilan alami, industri farmaseutik, kosmetik dan penjagaan peribadi.

Kata kunci: Aktiviti antibakteria; fraksi bes; Polyalthia cinnamomea; siklosiloksana

\section{INTRODUCTION}

Polyalthia cinnamomea Hook.f. \& Thomson that belongs to the family Annonaceae is widely found in lowland forest and widespread in Peninsula Malaysia and Singapore (Ridley 1967). Species of the Annonaceae are used all over the tropics in traditional medicine (Chkrabarti \& Mukherjee 1968; FRIM 2016; Irausin et al. 2014; Manasa et al. 2004; Supaluk et al. 2009; Sumitra \& Rathish 2010; Yamaguchi et al. 1964). The genus Polyalthia itself hold the meaning of 'many to cure' in Greek (poly-many altheato cure). In many parts of India, Polyalthia longifolia is used in the Indian traditional system of medicine including Ayurveda (Bapuji \& Ratnam 2009; Mahajan et al. 2010;
Patel 2010; Poornima et al. 2012; Sinhababu \& Baherjee 2013; Sugumaran et al. 2010; Sundaresan \& Senthil 2013). The stem extract of $P$. longifolia was found to inhibit the growth of gram positive and gram negative bacteria (Faizi et al. 2003) while its methanol extract of leaves and green berries were found to possess promising antibacterial activity (Faizi et al. 2008). Polyalthia cerasoides on the other hand, was used as medicinal plant in Thailand. Its roots were made as tonic and febrifuge (Pharmaceutical Sciences 1996). As for Annonaceae plant species, it is well known that the species are active biologically and produced many promising phytocomponents (Faizi et al. 2003; Lertyot et al. 2011; Patoomratna et al. 2000). 
Cyclomethicones are group of methyl siloxanes which is a class of liquid silicones that have the characteristics of low viscosity, high volatility and act as cosmetic solvents. They are particularly suited for use with other silicones and as delivery vehicles for a variety of active ingredients (Starch 2016). Cyclomethicone compounds can be found in plant that eventually influenced the potentiality of the plant antibacterial activity. From the previous study, the GC-MS analysis showed that the cyclomethicone components of the olive leaf extract caused the antimicrobial influence against thirteen bacteria whereby the first three major components of the extracts were cyclomethicones (hexamethylcyclotrisiloxane $36.98 \%$, octamethylcyclotetrasiloxane $15.18 \%$, decamethylcyclopentasiloxane 14.59\%) (Dilek et al. 2012). Besides, the other previous study showed that Toddalia asiatica was used traditionally as medicine to treat various ailments, contained cyclomethicone phytocomponents (Arun \& Varsha 2014).

All in all, many studies have been conducted to evaluate the bioactivity of the Polyalthia plant species as they are bioactively potent and consist of various bioactive compounds. Despite of all the studies, there were no study recorded on the specific plant of Polyalthia cinnamomea where its bioactivity and phytocomponents are still remain unknown. Hence, in this study, the leaf extract of the plant was obtained and the antibacterial activity against five gram positive bacteria and five gram negative bacteria were investigated and the major phytocomponents of the leaf extract were analyzed.

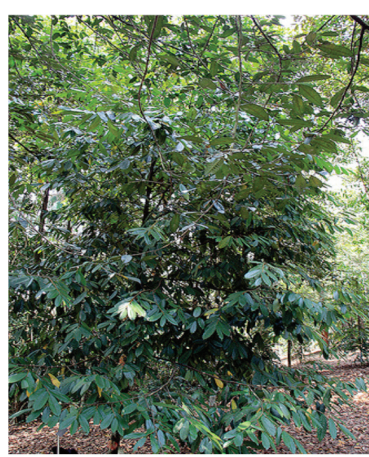

P. Cinnamomea

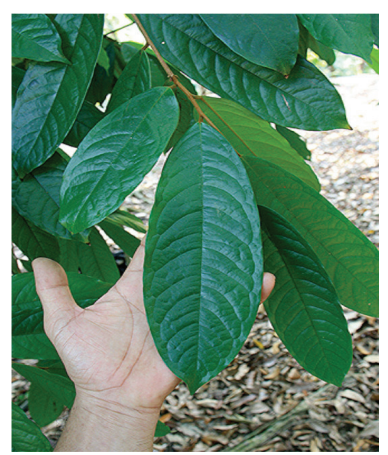

P. cinnamomea leaves

\section{MATERIALS AND METHODS}

\section{PLANT MATERIAL COLLECTION AND IDENTIFICATION}

The part of Polyalthia cinnamomea studied was the leaf. It was collected from Hutan Simpan Universiti Kebangsaan Malaysia Bangi, Selangor. The plant species was identified by Mr. Sani Miran, a botanist of Universiti Kebangsaan Malaysia. For further reference, the plant voucher specimen of 115D was deposited at the Universiti Kebangsaan Malaysia Herbarium (UKMB).

\section{EXTRACTION OF LEAVES EXTRACT}

The plant leaves were detached and air dried. After the drying, the leaves were grounded into powder by using a mechanical grinder. In an empty, used and cleaned chloroform glass bottle, $300 \mathrm{~g}$ of the grounded Polyalthia cinnamomea leaves were soaked in $1.8 \mathrm{~L}$ methanol for three days with regular shaking. After that, the methanol extract was filtered using cotton wool and the filtrate was evaporated under vacuum using Buchi rotary evaporator at the temperature of less than $40^{\circ} \mathrm{C}$ and with $110 \mathrm{rpm}$ rotation until $1 / 10$ of its original volume (Neli et al. 2011). The concentrated extract was used for the extraction of organic base components, most probably of cyclomethicones, following the method of Hadi and Bremner (2001) with some minor modifications and yielded $0.1 \mathrm{~g}$ of leaf extract. It was stored under $4^{\circ} \mathrm{C}$ prior to use.

\section{PREPARATION OF EXTRACT FOR ANTIBACTERIAL ASSAY}

Stock solution of the test Polyalthia cinnamomea extract was prepared from concentration of $10 \mathrm{mg} / \mathrm{mL}$ for discdiffusion method (methanol as solvent) and $30 \mathrm{mg} / \mathrm{mL}$ for minimum inhibitory concentration method (dimethyl sulfoxide, DMSO, as solvent). For disc-diffusion method, blank discs were prepared from the cut out of filter paper Whatman No. 2 and sterilized using autoclave machine at $120-124^{\circ} \mathrm{C}$ for $1-2 \mathrm{~h}$ before being loaded with $10 \mathrm{mg} / \mathrm{mL}$ concentration of the test extract and allowed to air dry at room temperature before use.

\section{BACTERIAL STRAINS}

The five gram-positive bacterial strains of Staphylococcus aureus ATCC 25923, Staphylococcus epidermidis, Bacillus subtilis ATCC 11774 , B. thuringiensis ATCC 10792, Methicilin resistant $S$. aureus (MRSA) and the five gram-negative bacteria strains of Escherichia coli ATCC 10536, Salmonella thyphimurium ATCC 51812, Serratia marcescens ATCC 13880, Vibrio cholera and Vibriofluvialis were used. They were obtained from the Microbiology Laboratory culture collection, School of Biosciences and Biotechnology, Faculty of Science and Technology, Universiti Kebangsaan Malaysia.

\section{PREPARATION OF CULTURE MEDIA FOR ANTIBACTERIAL ASSAY MUELLER-HINTON AGAR (MHA) AND MUELLER- HINTON BROTH (MHB)}

To prepare MHA, $800 \mathrm{~mL}$ distilled water was added to a Schott bottle $(1 \mathrm{~L})$ containing $19 \mathrm{~g}$ of MHA powder. Meanwhile, to prepare MHB, $200 \mathrm{~mL}$ distilled water was added to a Schott bottle $(500 \mathrm{~mL})$ containing $4.4 \mathrm{~g}$ of MHB powder. The two mixtures were then shaken thoroughly to dissolve the powder. Then, $10 \mathrm{~mL}$ of the MHB solution was poured into 10 universal bottles $(20 \mathrm{~mL})$ and $5 \mathrm{~mL}$ of the same solution was poured into 10 universal bottles $(10 \mathrm{~mL})$. After that, the MHA and MHB solutions were sterilized for $1-2 \mathrm{~h}$ at $120-124^{\circ} \mathrm{C}$ using an autoclave machine. As for minimum inhibitory concentration 
method, Tween 80 solution was used instead of distilled water to prepare the MHB. The sterilized MHB was kept at $4^{\circ} \mathrm{C}$ until use and the MHA solution was used to prepare agar plates.

\section{PREPARATION OF AGAR PLATE}

The laminar hood was first sterilized with $70 \%$ ethanol, and all the empty disposable commercial plastic Petri dishes $(9 \times 9 \mathrm{~cm})$ were assembled in the laminar hood and sterilized using UV light for 15-30 min. Later, the sterilized MHA was poured into each of the disposable commercial plastic Petri dishes under the laminar hood; the Petri dishes were cooled under UV light for 15-30 min. Finally, the plates were covered and stored in the cool room to prevent contamination until use.

\section{PREPARATION OF BACTERIAL INOCULUMS}

The sterilized 10 universal bottles with $5 \mathrm{~mL}$ MHB solution were seeded with bacteria from the pure culture stock by a sterilized wire loop and incubated at $37^{\circ} \mathrm{C}$ for $24 \mathrm{~h}$ to obtain the culture. After $24 \mathrm{~h}$ incubation, $300 \mu \mathrm{L}$ of the culture were taken and put into the $10 \mathrm{~mL}$ sterilized MHB solution that was prepared earlier. The turbidity of culture was measured and standardized against the McFarland 0.5 (optical density of 0.13 at $625 \mathrm{~nm}$ ).

\section{DISC-DIFFUSION ASSAY}

The disc-diffusion assay according to CLSI (2009) and Scorzoni et al. (2007) was carried out to determine antibacterial activity of the leaf extract by measuring the inhibition diameter. The bacteria suspensions were loaded on a sterile cotton swabs and streaked over the dried surface of MHA plates for inoculation. The sterile filter paper discs with $6 \mathrm{~mm}$ in diameter were impregnated with the sample $(10 \mathrm{mg} / \mathrm{mL})$ and then placed on the inoculated agar. The plates were incubated at $37^{\circ} \mathrm{C}$ for $24 \mathrm{~h}$. The antibacterial activity was determined by measuring the diameter of inhibition zone against the bacteria. The inhibition zone was measured in millimeter including the disc diameter. The test was carried out in triplicate. Streptomycine $(10 \mu \mathrm{g})$, Vancomycine $(30 \mu \mathrm{g})$, Peniciline $(30 \mu \mathrm{g})$ and Kanamycine $(30 \mu \mathrm{g})$ were used as the positive controls. For this assay, the extract was dissolved in methanol. A disc which was impregnated with DMSO was used as the negative control.

\section{MINIMUM INHIBITORY CONCENTRATION (MIC) ASSAY}

MIC is to determine the lowest concentration of the assayed antibacterial agent that, under defined test conditions, inhibits the visible growth of the bacterium (CLSI 2011). MIC was evaluated on bacteria strain that showed sensitivity to the extracts in the disc-diffusion assay according to CLSI (2011) and Irith et al. (2008). MIC was carried out using broth dilution assay following two-fold serial micro-dilution using 96-well microtiter plates. $100 \mu \mathrm{L}$ of DMSO solution of the test extract was distributed into the first well and was serially two-fold diluted to obtain the extract concentration ranging from 16 to $0.06 \mathrm{mg} / \mathrm{mL}$. Using a micropipette, $50 \mu \mathrm{L}$ of the bacteria inoculums were then dispensed into each of the serially diluted extract. Each plate was only used for one bacterium. All tests were carried out in triplicate. For positive controls, Chloramphenicol (128 to $0.25 \mathrm{mg}$ / $\mathrm{mL}$ ) and Vancomycine (32 to $0.06 \mathrm{mg} / \mathrm{mL}$ ) were used. The preparation of these antibiotics stock solutions and ranges determination for MIC were according to Andrews (2006). Meanwhile, the last three wells of the line were used as negative control by filling the mixture of $50 \mu \mathrm{L}$ bacteria inoculums and $50 \mu \mathrm{L}$ DMSO and as for the growth control, the well was filled with $100 \mu \mathrm{L}$ of MHB and 50 $\mu \mathrm{L}$ sample. The covered plates were incubated at $37^{\circ} \mathrm{C}$ for $16-24 \mathrm{~h}$ in an incubator.

\section{DETERMINING BACTERIAL GROWTH USING MTT ASSAY}

M T T (3-[4,5-dime thy l thi a zol-2-yl]-2,5diphenyltetrazolium bromide) is a tetrazolium dye which can be reduced by the live bacteria into an insoluble purple formazan. Thus, the reagent therefore can be used to differentiate between the live and the dead bacteria (Stevens \& Olsen 1993). MTT was prepared by dissolving in a phosphate-buffered saline (PBS) solution at $0.2 \mathrm{mg} /$ $\mathrm{mL}$. In this study, the MTT assay was incorporated into the MIC method to visually differentiate between the live and the dead bacteria. After 16-24 $\mathrm{h}$ incubation in the MIC method, $50 \mu \mathrm{L}$ of MTT reagent was added into each well and the colour development was observed and recorded after $2 \mathrm{~h}$ incubation (Figures 1-9).

\section{GCMS ANALYSIS OF MAJOR CONSTITUENTS}

The leaf extract was subjected to Gas Chromatography and Mass Spectroscopy for identification of bioactive volatile major constituents. GC-MS analysis was performed on an Agilent 7890A gas chromatograph (GC) directly coupled to mass-spectrometer (MS) system of an Agilent 5975C inert MSD with triple-axis detector. The column used was polar

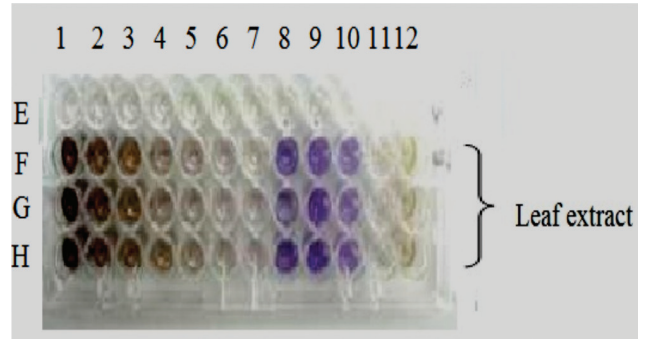

Microtiter plate wells F1-F9, G1-G9 and H1-H9 contain leaf extract ranges from 16 to $0.06 \mathrm{mg} / \mathrm{mL}$ in two-fold dilution. F10, G10 and H10 are negative control. F11, G11, H11 and F12, G12, H12 are growth control. E1-E9 is positive control

FIGURE 1. MIC determination for leaf extract of Polyalthia cinnamomea against methicilin resistant Staphylococcus aureus (MRSA) 


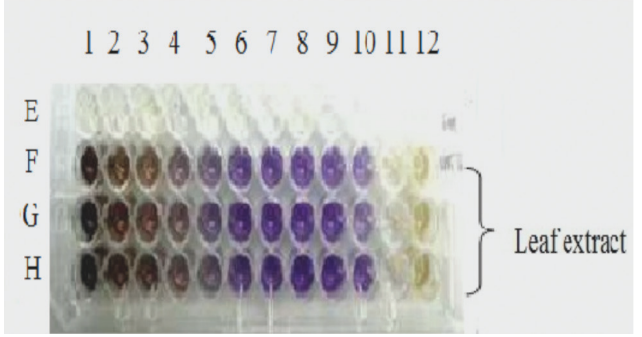

Microtiter plate wells F1-F9, G1-G9 and H1-H9 contain leaf extract ranges from 16 to $0.06 \mathrm{mg} / \mathrm{mL}$ in two-fold dilution. F10, G10 and $\mathrm{H} 10$ are negative control F11, G11, H11 and F12, G12, H12 are growth control. E1-E9 is positive control

FIGURE 2. MIC determination for leaves extract of Polyalthia cinnamomea against Staphylococcus aureus

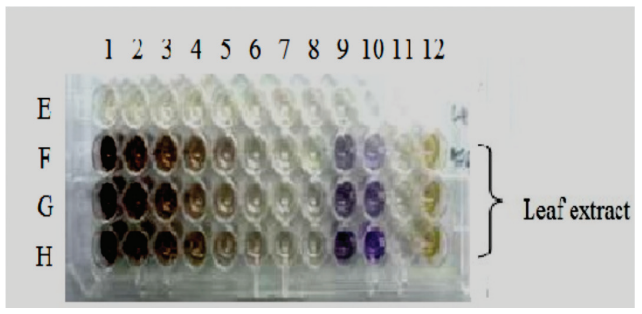

Microtiter plate wells F1-F9, G1-G9 and H1-H9 contain leaf extract ranges from 16 to $0.06 \mathrm{mg} / \mathrm{mL}$ in two-fold dilution. F10, G10 and H10 are negative control. F11, G11, H11 and F12, G12, H12 are growth control. E1-E9 is positive control

FIGURE 3. MIC determination for leaves extract of Polyalthia cinnamomea against Bacillus subtilis

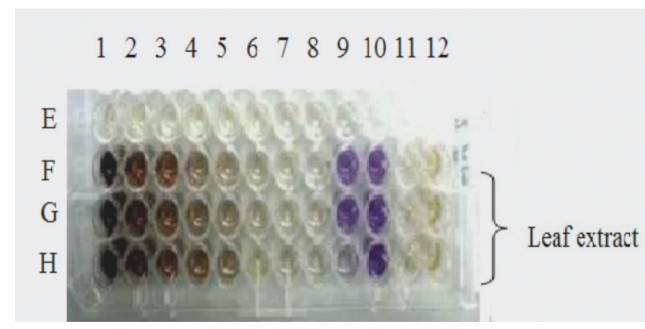

Microtiter plate wells F1-F9, G1-G9 and H1-H9 contain leaf extract ranges from 16 to $0.06 \mathrm{mg} / \mathrm{mL}$ in two-fold dilution. F10, G10 and $\mathrm{H} 10$ are negative control. F11, G11, H11 and F12, G12, H12 are growth control. E1-E9 is positive control

FIGURE 4. MIC determination for leaves extract of Polyalthia cinnamomea against Bacillus thuringiensis

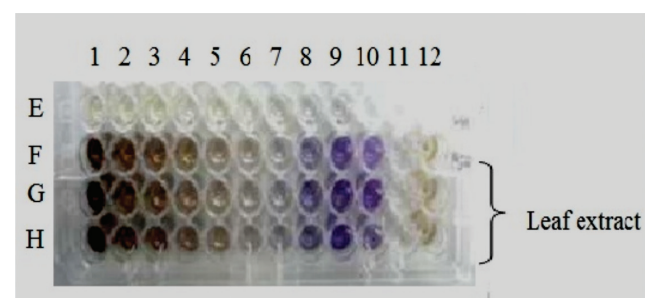

Microtiter plate wells F1-F9, G1-G9 and H1-H9 contain leaf extract ranges from 16 to $0.06 \mathrm{mg} / \mathrm{mL}$ in two-fold dilution. F10, G10 and H10 are negative control F11, G11, H11 and F12, G12, H12 are growth control. E1-E9 is positive control

FIGURE 5. MIC determination for leaves extract of Polyalthia cinnamomea against Salmonella thyphimurium

BP20(WAX) $(30 \mathrm{~m} \times 0.25 \mathrm{~mm} \times 0.25 \mu \mathrm{m})$ with polyethylene glycol stationary phase. Helium gas was used as the carrier

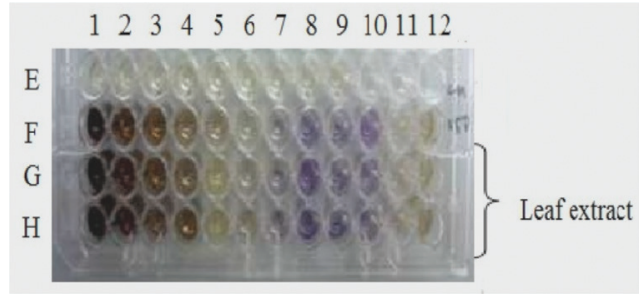

Microtiter plate wells F1-F9, G1-G9 and H1-H9 contain leaf extract ranges from 16 to $0.06 \mathrm{mg} / \mathrm{mL}$ in two-fold dilution. F10, G10 and $\mathrm{H} 10$ are negative control. F11, G11, H11 and F12, G12, H12 are growth control. E1-E9 is positive control

FIGURE 6. MIC determination for leaves extract of Polyalthia cinnamomea against Escherichia coli

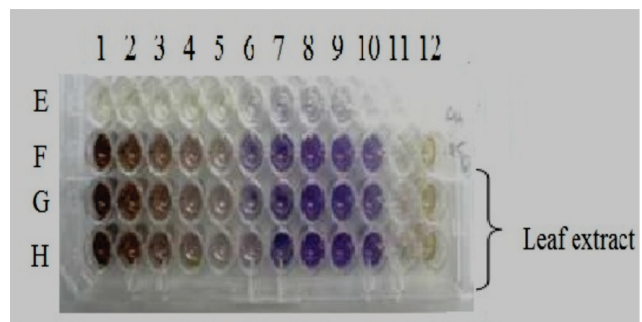

Microtiter plate wells F1-F9, G1-G9 and H1-H9 contain leaf extract ranges from 16 to $0.06 \mathrm{mg} / \mathrm{mL}$ in two-fold dilution. F10, G10 and H10 are negative control F11, G11, H11 and F12, G12, H12 are growth control. E1-E9 is positive control

FIGURE 7. MIC determination for leaves extract of Polyalthia cinnamomea against Vibrio fluvialis

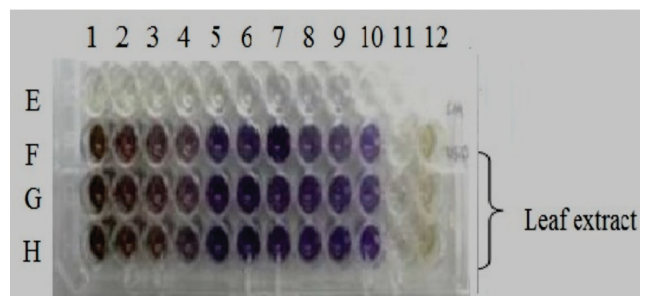

Microtiter plate wells F1-F9, G1-G9 and H1-H9 contain leaf extract ranges from 16 to $0.06 \mathrm{mg} / \mathrm{mL}$ in two-fold dilution. F10, G10 and $\mathrm{H} 10$ are negative control F11, G11, H11 and F12, G12, H12 are growth control. E1-E9 is positive control

FIGURE 8. MIC determination for leaves extract of Polyalthia cinnamomea against Vibrio cholera

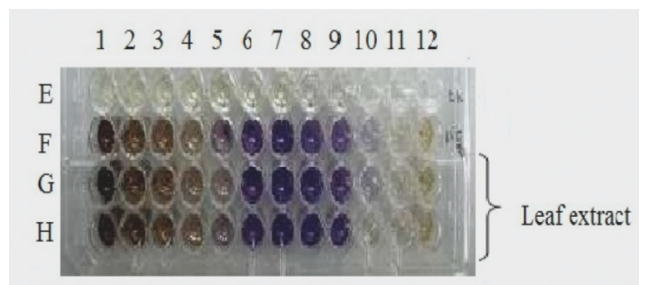

Microtiter plate wells F1-F9, G1-G9 and H1-H9 contain leaf extract ranges from 16 to $0.06 \mathrm{mg} / \mathrm{mL}$ in two-fold dilution. $\mathrm{F} 10, \mathrm{G} 10$ and $\mathrm{H} 10$ are negative control. F11, G11, H11 and F12, G12, H12 are growth control. E1-E9 is positive control

FIGURE 9. MIC determination for leaves extract of Polyalthia cinnamomea against Serratia mercescens

gas and the temperature programming was set with initial oven temperature at $50^{\circ} \mathrm{C}$ and held for $5 \mathrm{~min}$ and the final 
temperature of the oven was $250^{\circ} \mathrm{C}$ with rate at $5^{\circ} \mathrm{C} / \mathrm{min}$. A sample of $1 \mu \mathrm{L}$ was injected with split less mode. Total GC running time was $65 \mathrm{~min}$. The relative \% amount of each component was calculated by comparing its average peak area to the total area.

The MSD Chemstation was used to find all the peaks in the raw GC chromatogram. A library search was carried out for all the peaks using the NIST/EPA/NIH version 2.0 and the results were combined in a single peak table. Interpretation on mass spectrum GC-MS was done using the database of National Institute of Standard and Technology (NIST) having more than 62,000 patterns. The mass spectrum of the unknown component was compared with the spectrum of the known components stored in the NIST library. The names, molecular weights, retention times and peak area percentages of the test material were deduced.

\section{RESULTS AND DISCUSSION}

The leaf extract of Polyalthia cinnamomea showed a promising antibacterial activity against nine out of ten bacteria tested (Table 1). In disc-diffusion assay, the leaf extract inhibited four gram positive bacteria and five gram negative bacteria, of which the positive strain of Bacillus subtilis being the most inhibited one with the inhibition diameter of $19 \pm 4.6 \mathrm{~mm}$. There was no inhibition observed for Staphylococcus epidermidis. Meanwhile, the MIC results showed that the leaf extract gave the lowest minimum inhibitory concentration against the positive strain of Bacillus thuringiensis with the MIC value of $0.125 \mathrm{mg} / \mathrm{mL}$.

From the data obtained, it showed that the antibacterial activity of the leaf extract was more pronounced towards the gram positive bacteria strains compared to the negative ones, where the zone of inhibitions of the former were more prominent than those of the latter. These findings were in agreement with the observation of the previous study conducted regarding the antibacterial activity of medicinal plants, where most of the active plants showed potent activity against gram positive bacteria strains (Ali et al. 2001; Herrera et al. 1996; Karou et al. 2005; Kelmanson et al. 2000; Masika \& Folayane 2002; Nair et al. 2007; Puteri et al. 2017; Rabe \& Van 1997).

It was reported that gram positive bacteria strains only have one peptidoglycan layer compared to gram negative bacteria strains which have two. Thus, gram positive bacteria strains did not have an effective barrier to the lipophilic solutes while the gram negative bacteria strains have outer phospholipidic membrane that makes the cell wall impermeable to liphophilic solutes, while the porines constitute a selective barrier to hydrophilic solutes with an exclusion limit of about $600 \mathrm{Da}$ (Nikaido \& Vaara 1985; Scherrer \& Gerhardt 1971). Hence, the observation of the antibacterial activity in this study showed potent antibacterial activity against gram positive bacteria strains.

The inhibition zone data was statistically calculated and analyzed through one way analysis of variance (ANOVA) to obtain the F value and $\mathrm{P}$ value. Values of $p<0.05$ were considered statistically significant and the data are presented in Table 2.

The Polyalthia cinnamomea leaf extract used in this study has never been evaluated for its phytochemical components. The major phytocomponents of the leaf extract of $P$. cinnamomea has been discovered by using the GC-MS. The GC-MS chromatogram of the leaf extract of $P$. cinnamomea showed four major peaks representing four major phytocomponents (Figure 10). They are cyclosiloxane mixtures of octamethylcyclotetrasiloxane (18.12\%), decamethylcyclopentasiloxane (16.41\%), dodecamethylcyclohexasiloxane (14.06\%) and tetradecamethylcycloheptasiloxane (6.03\%) (Table 3).

To the best of our knowledge, there is no report on the chemical composition nor any bioactivities of the $P$. cinnamomea plant extract. But, previous studies of other plant extracts showed that the isolated octamethylcyclotetrasiloxane, decamethylcyclopentasiloxane and other cyclomethicones are well known antimicrobial and antifungal compounds (Koç et al. 2007; Yusof et al. 2008; Zhen et al. 2008). Other previous study also showed that the antibacterial properties of olive leaf extract were suspected to be associated with the high content of hexamethylcyclotrisiloxane (Hajji et al. 2010). Besides,

TABLE 1. Inhibition diameters and MIC values of antibacterial activity for Polyalthia cinnamomea leaf extract

\begin{tabular}{lccc}
\hline Bacteria/gram & $\begin{array}{c}\text { Inhibition diameter } \\
(\mathrm{mm})\end{array}$ & $\begin{array}{c}\text { Positive control } * \\
(\mathrm{~mm})\end{array}$ & $\begin{array}{c}\text { MIC } \\
(\mathrm{mg} / \mathrm{mL})\end{array}$ \\
\hline Methicilin Resistant S. aureus (MRSA)/+ & $10.3 \pm 0.6$ & $17 \pm 1.0$ & \\
Staphylococcus aureus/+ & $12.3 \pm 0.6$ & $14.3 \pm 1.2$ & 4.0 \\
Staphylococcus epidermidis/+ & N.I & $15.7 \pm 0.6$ & 4.0 \\
Bacillus subtilis/+ & $19.0 \pm 4.6$ & $34.0 \pm 11.0$ & 0.25 \\
Bacillus thuringiensis/+ & $6.7 \pm 1.1$ & $23.3 \pm 1.2$ & 0.125 \\
Salmonella typhimurium/- & $7.7 \pm 2.9$ & $25.0 \pm 0.3$ & 2.0 \\
Serratia marcescens/- & $6.7 \pm 1.2$ & $27.3 \pm 1.5$ & 4.0 \\
Escherichia coli/- & $7.0 \pm 1.7$ & $15.3 \pm 2.9$ & 1.0 \\
Vibrio fluvialis/- & $12.6 \pm 1.2$ & $29.3 \pm 1.2$ & 0.5 \\
Vibrio cholera/- & $7.6 \pm 0.6$ & $10.7 \pm 1.2$ & 16.0 \\
\hline
\end{tabular}

NI - No inhibition, *Antibiotic Kanamycine for all bacteria except B. subtilis (Peniciline) and MRSA, B. thuringiensis, S. epidermidis, S.typhimurium (Vancomycine) S. aureus (Streptomycine) 
TABLE 2. One way ANOVA for the antibacterial activity of Polyalthia cinnamomea leaf extract

\begin{tabular}{|c|c|c|c|c|}
\hline Bacteria/gram & $\begin{array}{l}\text { Inhibition diameter } \\
\qquad(\mathrm{mm})\end{array}$ & $\begin{array}{l}\text { Positive control* } \\
\text { (mm) }\end{array}$ & $\mathrm{F}$ value & $P$ value \\
\hline Methicilin Resistant S.aureus (MRSA)/+ & $10.3 \pm 0.6$ & $17 \pm 1.0$ & 8.96 & 0.0005 \\
\hline Staphylococcus aureus/+ & $12.3 \pm 0.6$ & $14.3 \pm 1.2$ & 7.19 & 0.055 \\
\hline Staphylococcus epidermidis/+ & N.I & $15.7 \pm 0.6$ & & \\
\hline Bacillus subtilis/+ & $19.0 \pm 4.6$ & $34.0 \pm 11.0$ & 4.75 & 0.0947 \\
\hline Bacillus thuringiensis/+ & $6.7 \pm 1.1$ & $23.3 \pm 1.2$ & 312.10 & 0.0001 \\
\hline Salmonella typhimurium/- & $7.7 \pm 2.9$ & $25.0 \pm 0.3$ & 108.12 & 0.0001 \\
\hline Serratia marcescens/- & $6.7 \pm 1.2$ & $27.3 \pm 1.5$ & 314.57 & 0.0001 \\
\hline Escherichia coli/- & $7.0 \pm 1.7$ & $15.3 \pm 2.9$ & 18.38 & 0.0128 \\
\hline Vibrio fluvialis/- & $12.6 \pm 1.2$ & $29.3 \pm 1.2$ & 320.52 & 0.0001 \\
\hline Vibrio choleral- & $7.6 \pm 0.6$ & $10.7 \pm 1.2$ & 16.30 & 0.0156 \\
\hline
\end{tabular}

*Antibiotic Kanamycine for all bacteria except B. subtilis (Peniciline) and MRSA, B. thuringiensis, S. epidermidis, S.typhimurium (Vancomycine) S. aureus (Streptomycine)

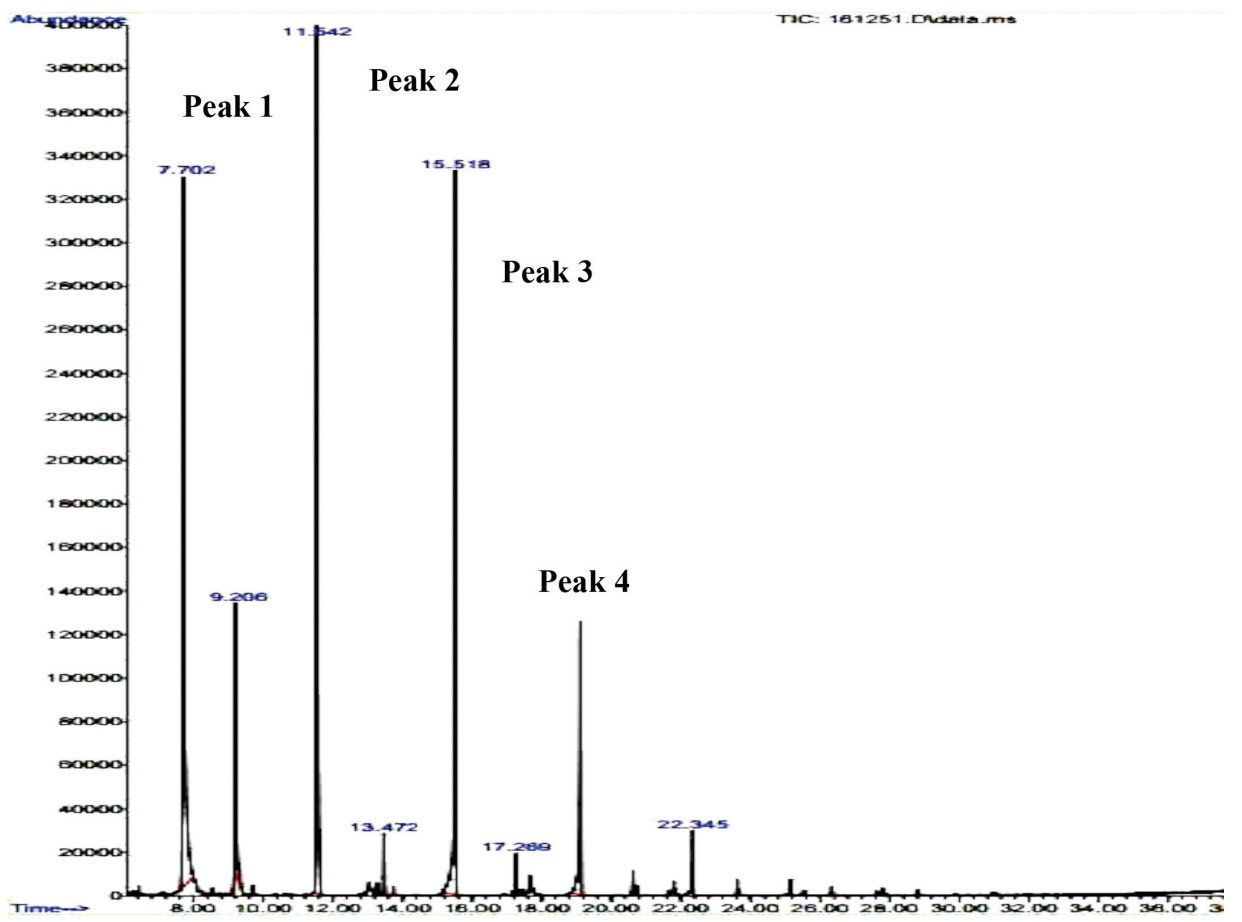

FIGURE 10. GC-MS chromatogram of the leaf extract of Polyalthia cinnamomea

in previous study, the oil derived from Pterocephalus canus that has dodecamethylcyclohexasiloxane showed significant antimicrobial activity against Staphylococcus saprophyticus and Escherichia coli (Moustafa et al. 2013).

Meanwhile, an aqueous extract from the leaves of Casimiroa edulis effectively controls in-vitro development of the post-harvest fungi Alternaria spp., Fusarium spp., Pestalotiopsis spp. and Rhizopus spp (Abou-elela et al. 2009) and GC-MS analysis showed it contains tetradecamethylcycloheptasiloxane (Vahedi et al. 2011). Furthermore, the phytocompounds of the methanolic extract of in vitro leaf in Spermacoce articularis showed the presence of cyclomethicone mixtures of dodecamethylcyclohexasiloxane $(5.93 \%)$, tetradecamethylcycloheptasiloxane $(4.04 \%)$ and hexadecamethylcyclooctasiloxane (2.29\%) which indicates to be an antimicrobial agent and the plant was used traditionally to treat various ailments (Bautista et al. 2000).

The result presented in this study may suggest that the leaf extract of Polyalthia cinnamomea possesses antibacterial properties and it can be a potential source of antibacterial ingredients for the pharmaceutical industry. Furthermore, a recent research has indicated that many chemical compounds, which present in high amounts in several plants exhibited bioactive properties like antimicrobial, antifungal, anti-inflammatory and antioxidant (Barakat 2011; Shalini \& Rachana 2009). Thus, it is justified that in this study, the major components of cyclosiloxanes in P. cinnamomea extract might be responsible for its potent antibacterial activity. 
TABLE 3. Major phytocomponents identified in leaf extract of Polyalthia cinnamomea

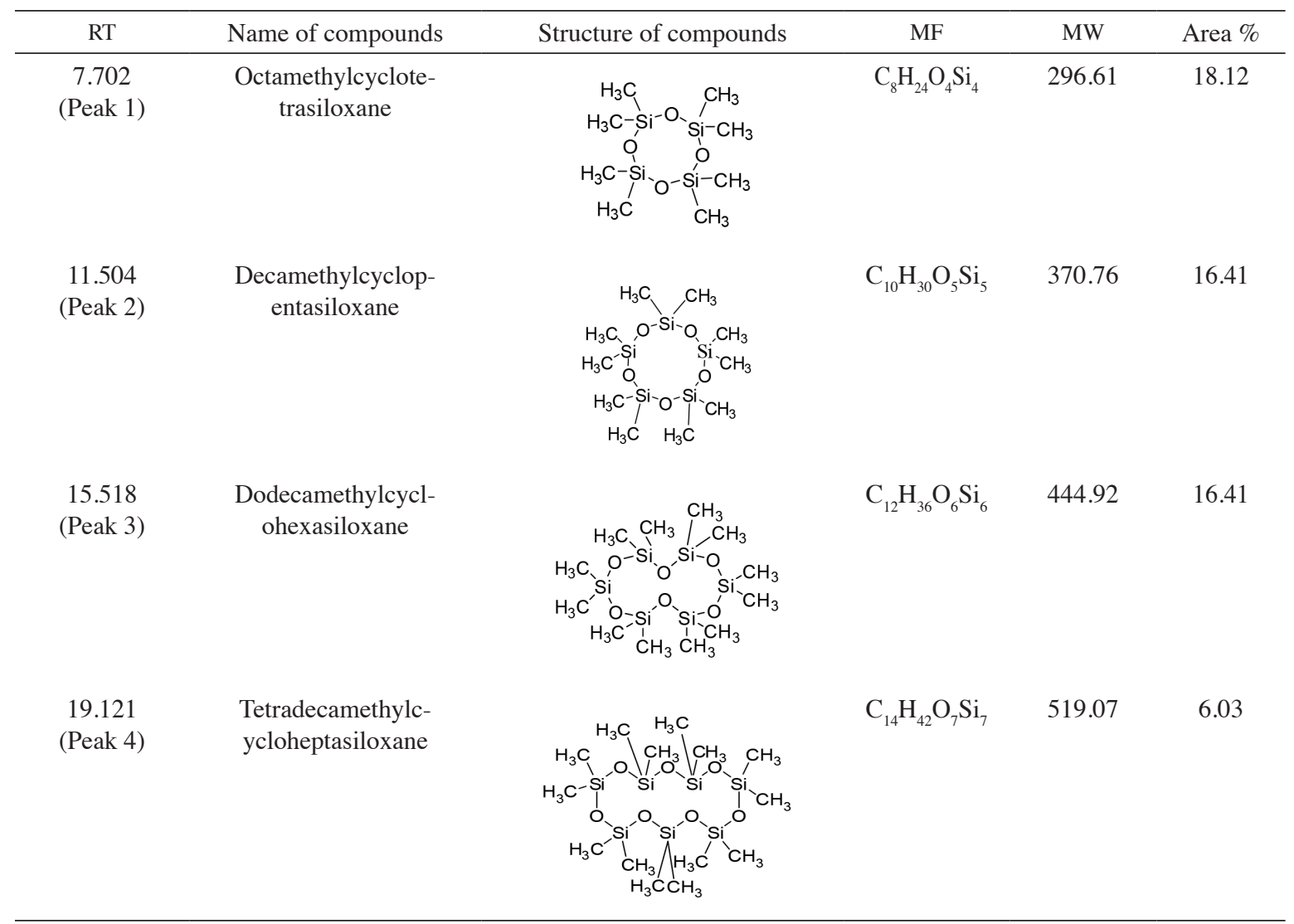

\section{CONCLUSION}

In conclusion, the leaf extract showed sensitivity towards both gram positive and gram negative bacteria but more pronounced towards the gram positive bacteria strains. The phytochemical analysis of the extract showed the presence of four major components of cyclosiloxane mixtures of octamethylcyclotetrasiloxane (18.12\%), decamethylcyclopentasiloxane $(16.41 \%)$, dodecamethylcyclohexasiloxane $(14.06 \%)$ and tetradecamethylcycloheptasiloxane $(6.03 \%)$. Thus, from the findings it suggested that the major components of cyclosiloxanes in P.cinnamomea leaf extract might be responsible for its potent antibacterial activity as the data obtained from this study mostly showed a statistically significant value with the control $(p<0.05)$. However further study need to be conducted to confirm the correlation between the major components and its antibacterial activity.

\section{ACKNOWLEDGEMENTS}

We would like to thank Universiti Kebangsaan Malaysia (UKM) and the Ministry of Higher Education (MOHE), Malaysia for allocating the grant DLP-2013-18, also to LPDP (Indonesia Endowment Fund for Education), DIKTI and the Ministry of Science and Technology and Universiti Kebangsaan Malaysia for financial support through research grant of FRGS-1-2014-SG01-UKM-02-5,
GUP-2017-103, respectively. We also would like to express our gratitude to Centre for Research and Instrumental Management (CRIM-UKM) for analytical instrument support. Thanks also go to all the lecturers of the School of Chemical Sciences and Food Technology and School of Biosciences and Biotechnology UKM for their continuous support, encouragement and valuable ideas. We would also like to express our gratitude to all laboratory assistants especially of the Laboratories L126 (Chemistry building) 3148, 3146 (Biology building), undergraduate and postgraduate students at the laboratories for their assistance in laboratory works.

\section{REFERENCES}

Abou-elela, G., Abd-lnaby, H., Ibrahim, H.A.H. \& Okbah, M.A 2009. Marine natural products and their potential applications as anti-infective agents. World Applied Science 7(7): 872-880.

Ali, N.A.A., Jülich, W.D., Kusnick, C. \& Lindequist, U. 2001. Screening of Yemeni medicinal plants for antibacterial and cytotoxic activities. Journal of Ethnopharmacology 74(2): 173-179.

Andrews, J.M. 2006. Determination of minimum inhibitory concentration. Journal of Antimicrobial Chemotherapy 48(suppl_1): 5-16.

Arun Patil \& Rathod, V.J. 2014. GC-MS analysis of bioactive components from methanol leaf extract of Toddalia asiatica (L.). International Journal of Pharmaceutical Sciences Review and Research 29(1): 18-20. 
Bapuji, L.J. \& Ratnam, V.S. 2009. Traditional uses of some medicinal plants by tribals of Gangaraju Madugula Mandal of Visakhapatnam district, Andhra Pradesh. Ethnobotanical Leaflets 13: 388-398.

Barakat, D.A. 2011. Insecticidal and antifeedant activities and chemical composition of Casimiroa edulis la llave \& lex (rutaceae) leaf extract and its fractions against spodoptera littoralis larvae. Journal of Applied Sciences Research 5(9): 693-703.

Bautista-baños, S., Hernández-López, M. \& Barrera-Necha, L.L. 2000. Antifungal screening of plants of the state of morelos, Mexico against four fungal postharvest pathogens of fruits and vegetables. Journal of Natural Products 18: 36-41.

Chkrabarti, S.K. \& Mukherjee, B. 1968. Search for anticancer drug from Indian medicinal plants. Indian Journal of Medicinal Research 56: 445-455.

CLSI. 2011. Clinical and Laboratory Standard Institute Performance Standards for Antimicrobial Susceptibility Testing. Wayne, Pennslyvania, National Committee for Clinical Laboratory Standards. M100-S21.

CLSI. 2009. Clinical and Laboratory Institute Performance Standards for Antimicrobial Disk Susceptibility Tests. Wayne, Pennsylvania, National Committee for Clinical Laboratory Standard. M02-A10.

Karou, D., Savadogo, A., Canini, A., Yameogo, S., Montesano, C., Simpoe, J., Colizzi, V. \& Traore, A.S. 2005. Antibacterial activity of alkaloids from Sida acuta. African Journal of Biotechnology 4(12): 1452-1457.

Dilek Keskin, Nur Ceyhan, A. Ugur \& Ayse Durgan Dbeys. 2012. Antimicrobial activity and chemical constituents of West Anatolia olive (Olea europaea L.) leaves. Journal of Food and Environment 10(2): 99-102.

Faizi, S., Khan, R.A., Mughal, N.R., Malik, M.S., Sajjadi, K.E. \& Ahmad, A. 2008. Antimicrobial activity of various. Parts of Polyalthia longifolia var. pendula: Isolation of active principles from the leaves and the berries. Phytotherapy Research 22(7): 907-912.

Faizi, S., Mughal, N.R., Khan, R.A., Khan, S.A., Ahmad, A., Bibi, N. \& Ahmed, S.A. 2003. Evaluation of the antimicrobial property of Polyalthia longifolia var. pendula: Isolation of a lactone as the active antibacterial agent from the ethanol extract of the stem. Phytotherapy Research 17(10): 11771781.

Faizi, S., Khan, R.A., Azher, S., Khan, S.A., Tauseef, S. \& Ahmad, A. 2003. New antimicrobial alkaloids from the roots of Polyalthia longifolia var. pendula. Plant Medica 69: 350-355.

Hadi, S. \& Bremner, J. 2001. Initial studies on alkaloids from Lombok medicinal plants. Molecules 6: 117-129.

Hajji, M., Jarraya, R., Lassoued, I., Masmoudi, O., Damak, M. \& Nasri, M. 2010. GC/MS and LC/MS analysis, and antioxidant and antimicrobial activities of various solvent extracts from Mirabilis jalapa tubers. Process Biochemistry 45(9): 1486-1493.

Herrera, R.M., Pérez, M., Martín-Herrera, D.A., López-García, R., Rabanal, R.M. \& Arias, A. 1996. Antimicrobial activity of extracts from plants endemic to the Canary Islands. Phytotherapy Research 10(4): 364-366.

Irausin, G., Lima, R.B.S., Hidalgo, A.D.F., Maas, P. \& Pohlit, A.M. 2014. Plants of the Annonaceae traditionally used as antimalaria: A review. Edico Especial 36: 315-336.

Irith, W., Kai, H. \& Hancock, R.E.W. 2008. Agar and broth dilution methods to determine the minimal inhibitory concentration (MIC) of antimicrobial substances. Nature Protocols 3: 163-175.

Kelmanson, J.E., Jager, A.K. \& Van Staden, J. 2000. Zulu medicinal plants with antibacterial activities. J. Ethnopharmacol 69: 241-246.

Koç, A.N., Silici, S., Mutlu-Sariguzel1, F. \& Sagdic, O. 2007. Antifungal activity of propolis in four different fruit juices. Food Technology and Biotechnology 45(1): 57-61.

Yusuf Kurt, M. Suleyman, K. \& Kani Isik. 2008. Traditional tar production from Cedrus libani rich on the taurus mountains in Southern Turkey. Economic Botany 62(4): 615-620.

Lertyot Treeratanapiboon, Apilak Worachartcheewan, Thummaruk Suksrichavalit, Rachada Kiatfuengfoo, Supaluk Prachayasittikul, Somsak Ruchirawat \& Virapong Prachyasittikul. 2011. Bioactive 4-hydroxycinnamide and bioavtivities of polyalthia cerosoides. Molecules 10: 16-22.

Mahajan, S.K., Khare, B., Mahajan, D.D., Gupta, V., Muwel, S.L., Gupta, M. \& Mahajan, P. 2010. Folk medicinal uses of plants against malignant tumor in Khargone district of M.P. India Journal of Environmental Research and Development 4(3): 800-802.

Manasa, M., Vivek, M.N., Yashoda, K., Onkarappa, R. \& Prashith K.T.R. 2004. Antimicrobial activity of leaf and pericarp extracts of Polyalthia longifolia (Annonaceae). Journal of Pharmaceutical and Scientific Innovation 393: 221-225.

Masika, P.J. \& Afolayane, A.J. 2002. Antimicrobial activity of some plants used for the treatment of livestock disease in Eastern Cape, South Africa. J. Ethnopharmacol 83: 129-134.

Ministry of Natural Resources and Environment Forest Reseacrh Institute Malaysia (FRIM). Clearing House Mechanism Biological Diversity Database. http://www.chm.frim. gov.my/Bio-diversity-Database/flora-Database/Polyalthia cinnamomea. Accessed on 13 January 2016.

Moustafa, M.F.M., Alamri, S.A., Taha, T.H. \& Alrumman, S.A. 2013. In vitro antifungal activity of Argemone ochroleuca sweet latex against some pathogenic fungi. African Journal of Biotechnology 12(10): 1132-1137.

Nair, R. \& Sumitra, C. 2007. In-vitro antimicrobial activity of Psidium guajava leaf extracts against clinically important pathogenic microbial strains. Brazilian Journal of Microbiology 38(3): 452-458.

Neli, L.P., Yogendra, K., Berington, M., Ranjan, K.B. \& Santaram, J. 2011. In vitro antibacterial activity of alkaloid extract from stem bark of Mahonia manipurensis Takeda. Journal of Medicinal Plants Research 5(5): 859-861.

Nikaido,H. \& Vaara,M. 1985. Molecular basis of bacterial outer membrane permeability. Microbiol. Rev. 1: 1-32.

Patel, N.K. 2010. Ethno-medicinal plants used for gonorrhea disease in Danta Taluka (Gujarat). Ethno-Botanical Leaflets 14: 642-647.

Patoomratana Tuchinda, Marat Pohmakotr, Bamroong Munyoo, Vichai Reutvakul \& Thawatchai Sentisuk. 2000. An azaanthracene alkaloid from Polyalthia suberosa. Elsevier Phytochemistry 53: 1079-1082.

Poornima, G., Mansa, M., Rudrappa, D. \& Kekudda, P.T.R. 2012. Medicinal plants used by herbal healers in Narasipura and Manchale villages of Sagara Taluk, Karnataka, India. Science, Technology and Arts Research Journal 1(2): 12-17.

Puteri I.A.M. Mahmud, Yaacob, W.A. \& Ibrahim, N. 2017. Antibacterial activity of alkaloid extracts from Ochrosia oppositifolia. Sains Malaysiana 46(8): 1279-1284.

Rabe, T. \& Van Staden, J. 1997. Antibacterial activity of South African plants used for medicinal purposes. $J$. Ethnopharmacol. 56: 81-87. 
Ridley, S.N. 1967. The Flora of the Malay Peninsula. London: L.Reeve \& Co.Ltd. pp. 51-52.

Sinhababu, A. \& Baherjee, A. 2013. Ethno-botanical study of medicinal plants used by tribals of Bankura Districts, West Bengal, India. Journal of Medicinal Plants Studies 1(3): 98-104.

Scherrer, R. \& Gerhardt, P. 1971. Molecular Sieving by the Bacillus megaterium cell wall and protoplast. J. Bacteriol 107: 718-735

Scorzoni, L., Benaducci, T., Almeida, A.M.F., Silva, D.H.S., Bolzani, V.S. \& Mendes Giannini, M.J.S. 2007. Comparative study of disk diffusion and microdilution methods for evaluation of antifungal activity of natural compounds against medical yeast Candida spp and Cryptococcus sp. Journal of Basic and Applied Pharmaceutical Sciences 28(1): 25-34.

Shalini \& Srivastava, R. 2009. Antifungal activity screening and HPLC analysis of crude extract from Tectona grandis, Shilajit, Valeriana wallachi. Electronic Journal of Environmental, Agricultural and Food Chemistry 8(4): 218-229.

Starch, M.S. 2008. Silicones' benefits in antiaging skin care. Cosmetics and Toiletries: Science Applied. http:// www.coemeticsandtoiletries.com/formulating/category/ antiaging/34408409.html. Accessed on 23 January 2016.

Pharmaceutical Sciences, Mohidal University. 1996. Bangkok: Siam-Phi-Chacha-Ya-Prug, Amarin Printing and Publishing. p. 190

Stevens, M.G. \& Olsen, S.C. 1993. Comparative analysis of using MTT and XTT in colorimetric assays for quantitating bovine neutrophil bactericidal activity. Journal of Immunological Methods 157(1-2): 225-231.

Sugumaran, M., Bharathi, V., Hemachander, R. \& Lakshmi, M. 2010. Ethnomedicinal plants for indigestion in Uthiramerur Taluk, Kancheepuram district, Tamil Nadu, India. Journal of Chemical and Pharmaceutical Research 2(6): 463-470.

Sumitra Chanda \& Rathish Nair. 2010. Antimicrobial activity of Polyalthia longifolia (Sonn.) thw. Var. pendula leaf extracts against 91 clinically important pathogenic microbial strains. Scientific Research Chinese Medicine 1: 31-38.

Sundaresan, S. \& Senthilkumar, B. 2013. A survey of traditional medicinal plants from the Vellore district, Tamil Nadu, India. International Journal of Ayurvedic and Herbal Medicine 3(5): 1347-1355.
Supaluk Prachayasittikul, Patumporn Manam, Maneekarn Chinworrungsee, Charychalerm Isarankura-Na-Ayudhya, Somsak Ruchirawat \& Virapong Prachayasittikul. 2009. Bioactive azafluorenone alkaloids from Polyalthia debilis (Pierre) Finet \& gagnep. Molecule 14: 4414-4424.

Vahedi, H., Nasrabadi, M., Lari, J. \& Halimi, M. 2011. Volatile constituents and antimicrobial activities of Pterocephalus canus. Journal of Medicinal Plants Research 5(23): 56465648.

Yamaguchi, K., Kinora, H., Natori, S., Ito, H., Nissbimio, K., Bando, K., Mizuno, D. \& Ishignoo, M. 1964. Screening tests for antitumor activity of Asian medicinal herbs I. $\mathrm{Ya}$ kugakuzashi 84: 373-377.

Zhen, H.S., Ge, J., Liang, J., Qiu, Q., Song, Z.H., Zhong, Z.G. Wang, W.H. \& Jiang, J.P. 2008. Analysis of the volatile oils chemical constituents of roots of Actinidia deliciosa. Zhong Yao Cai 31(5): 677-678

Puteri I.A.M.Mahmud, Wan A.Yaacob \& Muntaz Abu Bakar* School of Chemical Sciences and Food Technology

Faculty of Science and Technology

Universiti Kebangsaan Malaysia

43600 UKM Bangi, Selangor Darul Ehsan

Malaysia

Nazlina Ibrahim

School of Biosciences and Biotechnology

Faculty of Science and Technology

Universiti Kebangsaan Malaysia

43600 UKM Bangi, Selangor Darul Ehsan

Malaysia

*Corresponding author; email: muntaz@ukm.edu.my

Received: 31 March 2018

Accepted: 17 May 2018 